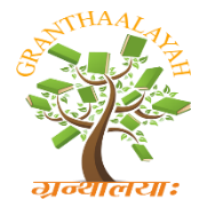

Social

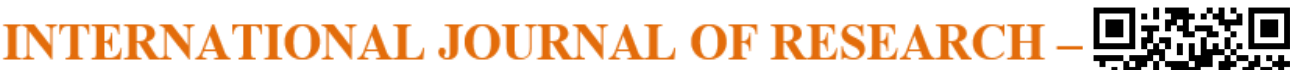 \\ GRANTHAALAYAH \\ A knowledge Repository
}

\section{AGGRESSIVE BEHAVIOUR AND EMOTIONAL MATURITY OF EARLY ADOLESCENTS}

\author{
Reena R S *1 \\ ${ }^{* 1}$ Assistant Professor, Bethlahem College of Education, Karungal, 629157, India
}

\begin{abstract}
The study conducted on aggressive behaviour and emotional maturity of early adolescent students. Survey method was adopted for the present study. A sample of 400 high school students was selected using the random sampling technique. The tools used in the study were Aggressive Behaviour Scale prepared by Km.Roma Pal (1971) and the same tool was validated by Krishna Raj (2012) and Emotional Maturity scale was developed by Dr Yashwir Singh and Mahesh Bhargava (1990). The investigator validated the items of the emotional maturity scale to check the suitability of the items. Percentage Analysis, "t" test, ANOVA, Scheffe test were the statistical techniques used in the study. The major finding of the study revealed that there is no significant relationship exists between aggressive behaviour and emotional maturity of early adolescent students.
\end{abstract}

Keywords: Aggressive Behaviour; Emotional Maturity; Adolescent Student \& School.

Cite This Article: Reena R S. (2018). "AGGRESSIVE BEHAVIOUR AND EMOTIONAL MATURITY OF EARLY ADOLESCENTS." International Journal of Research Granthaalayah, 6(10), 57-64. https://doi.org/10.29121/granthaalayah.v6.i10.2018.1161.

\section{Introduction}

Aggression is one of the most pressing issues in the current generation and in schools. It is also one of the most prevalent behavioral aspects in children which cause a lot of concern in the present days. Aggression engulfs a wide spectrum of behaviours, which varies from covert to overt display of aggressive behaviours. Aggression may be linked to the person's personality and behaviour. The aggressive behaviour might be the person's way of meeting the need, an attempt to communicate it, or an outcome of the unmet need. Aggressive behaviouris reactionary and impulsive behaviour that often results in breaking household rules or the law; aggressive behaviour is violent and unpredictable. The form, frequency and function of aggression changes with age, consequently in identifying and assessing if aggressive behaviour is a problem, it is important to consider the age of the child. For example, infants have limited communication skills and thus and aggression to communicate. The majority of children grow out of aggressive behviour by their mid teens and consequently anger and aggression are short lived and do not signal a problem. Most 
adolescents have well developed social skills and self-control and do not develop aggressive behaviour problems.

Emotional Maturity is an ability to understand and use one's emotional personality-controlled way. The more matured individual is more stable and flexible in adjustment. An emotionally mature person has the capacity to withstand delay in satisfaction of needs. He has the ability to tolerate a reasonable amount of frustration. An emotionally mature person has the capacity to make effective adjustment with himself, members of his family, his peers in the school, work place, society and culture. Emotional immaturity leads to general unhappiness as seen in the feelings to fear, failure, disappointment and stress. Such negative feelings affect the individual's performance. If a person attains emotional maturity he is able to demonstrate a well-balanced emotional behaviour in his day to day life. A person may be said to emotionally matured, if he has in his possession almost all types of emotions positive or negative and is able to express them at the appropriate time in an appropriate degree. Emotional maturity implies controlling our emotions more willingly than letting your emotions to give you the orders.

\section{Need for the Study}

In the Indian scenario also, we can see an alarming proportion of children in schools displaying aggressive behaviour like hitting, kicking, biting, scratching, destructive behaviors, teasing or verbally abusive language towards peers and adults. The most dangerous aggression occurs during the late teen years and in early adulthood. It is essential to develop emotional maturity in children to develop sense of direction, awareness of objectives for life, to develop organized and integrated emotional responses and ability to bear stress under calmness to develop control over emotions and develop consistency of emotional maturity and do right thing at the right time. The present study has its importance because aggressive behaviour is highly prevalent in children and hence need to study the factors which influence aggressive behaviour in children. Emotional immature adolescents are more prone to let out their emotional problems in more aggressive way. In the present study an attempt is made to find out the relationship between aggressive behavior and emotional maturity of early adolescents. So, the investigator has selected the topic, aggressive behaviour and emotional maturity of early adolescents.

\section{Objectives of the Study}

1) To find out the level of Aggressive Behaviour and Emotional Maturity of Early adolescents with regard to background variables.

2) To find out the significant difference if any, in the aggressive behavior of Early adolescents with regard to background variables

3) To find out the significant difference if any, in the emotional maturity of Early adolescents with regard to background variables

4) To find out the significant relation between aggressive behavior and emotional maturity of Early adolescents.

The background variables are gender and age.

\section{Hypotheses of the Study}

Ho1: There is no significant difference in the aggressive behavior of early adolescents with regard to background variables. 
Ho2: There is no significant difference in the emotional maturity of early adolescents with regard to background variables.

Ho3: There is no significant relation between aggressive behavior and emotional maturity of early adolescents.

The background variables are gender and age.

\section{Methodology}

In the present study investigator has used survey method to study the relationship between aggressive behavior and emotional maturity of early adolescent students in Kanyakumari District.

\section{Sample}

Sampling technique employed in this study was stratified random sampling and the sample size was 300 high school students in Kanyakumari District.

\section{Tools Used}

Aggressive Behaviour Scale was prepared by Km.Roma Pal (1971) and the same tool was validated by Krishna Raj (2012). The scale consisted of 24 statements.

Emotional Maturity scale was developed by Dr Yashwir Singh and Mahesh Bhargava (1990). The investigator validated the items of the emotional maturity scale to check the suitability of the items. All the statements in the scale are divided into 5 dimensions- emotional stability, emotional progression, social adjustment, personality integration and independence. It was a five point scale.

\section{Analysis of Data}

To interpret the raw scores meaningfully, the data were analyzed by using mean, standard deviation, 't' test, F-test, Schefffe test.

\section{Descriptive Analysis}

Table 1: Level of aggressive behaviour of male and female early adolescents

\begin{tabular}{|l|l|l|l|l|l|l|l|l|l|l|l|}
\hline \multicolumn{10}{|c|}{ Aggressive Behaviour } \\
\hline \multicolumn{9}{|c|}{ Male } & \multicolumn{6}{c|}{ Female } \\
\hline \multicolumn{2}{|c|}{ Low } & Average & \multicolumn{1}{c|}{ High } & \multicolumn{2}{|c|}{ Low } & \multicolumn{2}{|c|}{ Average } & \multicolumn{2}{c|}{ High } \\
\hline $\mathrm{N}$ & $\%$ & $\mathrm{~N}$ & $\%$ & $\mathrm{~N}$ & $\%$ & $\mathrm{~N}$ & $\%$ & $\mathrm{~N}$ & $\%$ & $\mathrm{~N}$ & $\%$ \\
\hline 74 & 42.8 & 66 & 38.2 & 33 & 19.1 & 13 & 10.2 & 61 & 48 & 53 & 41.7 \\
\hline
\end{tabular}

It is observed from the above table that the male and female early adolescents have average and low level of aggressive behavior.

Table 2: Level of emotional maturity of male and female early adolescents

\begin{tabular}{|c|c|c|c|c|c|c|c|c|c|c|c|c|}
\hline \multicolumn{13}{|c|}{ Emotional Maturity } \\
\hline \multirow[t]{3}{*}{ Dimension } & \multicolumn{6}{|c|}{ Male } & \multicolumn{6}{|c|}{ Female } \\
\hline & \multicolumn{2}{|c|}{ Low } & \multicolumn{2}{|c|}{ Average } & \multicolumn{2}{|c|}{ High } & \multicolumn{2}{|c|}{ Low } & \multicolumn{2}{|c|}{ Average } & \multicolumn{2}{|c|}{ High } \\
\hline & $\mathrm{N}$ & $\%$ & $\mathrm{~N}$ & $\%$ & $\mathrm{~N}$ & $\%$ & $\mathrm{~N}$ & $\%$ & $\mathrm{~N}$ & $\%$ & $\mathrm{~N}$ & $\%$ \\
\hline E.S & 64 & 37.0 & 45 & 26.0 & 64 & 37.0 & 46 & 36.2 & 26 & 20.5 & 55 & 43.3 \\
\hline
\end{tabular}




\begin{tabular}{|l|l|l|l|l|l|l|l|l|l|l|l|l|}
\hline E.P & 79 & 45.7 & 47 & 27.2 & 47 & 27.2 & 23 & 18.1 & 38 & 29.9 & 66 & 52.0 \\
\hline S.A & 73 & 42.2 & 51 & 29.5 & 49 & 28.3 & 27 & 21.3 & 35 & 27.6 & 65 & 51.2 \\
\hline P.I & 65 & 37.6 & 67 & 38.7 & 41 & 23.7 & 25 & 19.7 & 47 & 37.0 & 55 & 43.3 \\
\hline I & 80 & 46.2 & 53 & 30.6 & 40 & 23.1 & 29 & 22.8 & 62 & 48.8 & 36 & 28.3 \\
\hline Total & 72 & 41.6 & 60 & 34.7 & 41 & 23.7 & 18 & 14.2 & 53 & 41.7 & 56 & 44.1 \\
\hline
\end{tabular}

It is observed from the above table that in the dimensions emotional stability, emotional progression, social adjustment, independence and in total the male early adolescents have low level of emotional maturity but $38.7 \%$ of the $1 \mathrm{n}$ in the dimension personality integration have average level of emotional maturity. With regard to female early adolescents, in the dimensions emotional stability, emotional progression, social adjustment, personality integration and in total the female early adolescents have high level of emotional maturity but $48.8 \%$ of them in the dimension emotional stability have average level of emotional maturity.

\section{Differential Analysis}

Ho1: There is no significant difference in the aggressive behaviour of early adolescents with regard to gender.

Table 3: Significance of difference between male and female early adolescents in their aggressive behavior

\begin{tabular}{|c|c|c|c|l|l|l|}
\hline \multicolumn{7}{|c|}{ Aggressive behaviour } \\
\cline { 1 - 4 } Mean & S D & Mean & S D & & & \\
\cline { 1 - 4 } 52.6705 & 21.82944 & 64.0236 & 17.65969 & 4.817 & 0.000 & S \\
\hline
\end{tabular}

From the table 4.5 it is clear that the $\mathrm{P}$ - value is less than 0.05 at $5 \%$ level of significance. Hence the null hypothesis is not accepted. It shows that there is significant difference between male and female early adolescents in their aggressive behaviour.

H02: There is no significant difference in the aggressive behaviour of early adolescents with regard to age.

Table 4: Significance of difference in the aggressive behaviour of early adolescents with regard to age.

\begin{tabular}{|l|l|l|l|l|l|}
\hline \multicolumn{1}{|c|}{ Aggressive Behaviour } \\
\hline $\begin{array}{c}\text { Source of } \\
\text { variation }\end{array}$ & Sum square & Mean square & F-Value & P-Value & Remarks (5\%level) \\
\hline Between Groups & 3241.145 & 1620.572 & 3.776 & 0.024 & $\mathrm{~S}$ \\
\hline Within Groups & 127455.692 & 429.144 & & & \\
\hline
\end{tabular}

From the table 4.7 it is clear that the $\mathrm{P}$ - value is less than 0.05 at $5 \%$ level of significance. Hence the null hypothesis is not accepted. It shows that there is significant difference among early adolescents in their aggressive behaviour with regard to age. 
Table 4 (a): Scheffe test results of significance of difference among early adolescents in their aggressive behaviour with regard to age

\begin{tabular}{|l|l|l|l|}
\hline \multicolumn{3}{|c|}{ Aggressive Behaviour } & \multirow{2}{*}{ Remarks } \\
\cline { 1 - 3 } Age 13 & Age 14 & Age 15 & \\
\hline-- & 58.1223 & 57.2500 & -- \\
39.8000 & -- & 57.2500 & -- \\
39.8000 & 58.1223 & & $*$ \\
\hline
\end{tabular}

The scheffe test result shows that there is significant difference between age 13 and age 14 in their aggressive behaviour. The mean value of age 14 is greater than that of the others. It indicates that the age 14 students have better aggressive behaviour than the others.

H03: There is no significant difference in the emotional maturity of early adolescents with regard to gender.

Table 5: Significance of difference between male and female early adolescents in their emotional maturity

\begin{tabular}{|l|c|c|c|c|l|l|l|}
\hline \multicolumn{8}{|c|}{ Emotional Maturity } \\
\cline { 1 - 6 } Dimension & \multicolumn{2}{|c}{ Male } & \multicolumn{2}{c|}{ Female } & t- Value & P Value & Remarks \\
\cline { 2 - 8 } & Mean & S D & Mean & S D & & & \\
\hline ES & 20.2832 & 5.90483 & 20.5433 & 4.91960 & .404 & 0.687 & NS \\
\hline EP & 15.4682 & 5.95383 & 18.4173 & 5.58689 & 4.350 & 0.00 & S \\
\hline SA & 11.9480 & 5.57326 & 15.1024 & 5.54324 & 4.855 & 0.00 & S \\
\hline PI & 12.5607 & 6.39068 & 15.2441 & 5.24891 & 3.869 & 0.00 & S \\
\hline I & 14.6347 & 5.81587 & 16.4724 & 4.65445 & 3.895 & 0.00 & S \\
\hline Total & 74.2948 & 24.06314 & 85.7795 & 19.90330 & 4.388 & 0.00 & S \\
\hline
\end{tabular}

From the table 5 it is dear that the $\mathrm{P}$ - value is greater than 0.05 for the dimension emotional stability at 5\% level of significance. Hence the null hypothesis is accepted. It shows that there is no significant difference between male and female early adolescents in their emotional maturity. It is also clear that the $\mathrm{P}$ - value is less than 0.05 for the dimensions emotional progression, social adjustment, personality integration and independence at $5 \%$ level of significance, Hence the null hypothesis is not accepted. So there is significant difference between male and female early adolescents in their emotional maturity.

H04: There is no significant difference in the emotional maturity of early adolescents with regard to age.

Table 6: Significance of difference in the emotional maturity of early adolescents with regard to

\begin{tabular}{|l|l|l|c|c|c|c|}
\hline Dimension & $\begin{array}{c}\text { Source of } \\
\text { variation }\end{array}$ & $\begin{array}{c}\text { Sum } \\
\text { square }\end{array}$ & $\begin{array}{c}\text { Mean } \\
\text { square }\end{array}$ & $\begin{array}{c}\text { F- } \\
\text { Value }\end{array}$ & $\begin{array}{c}\text { P- } \\
\text { value }\end{array}$ & $\begin{array}{c}\text { Remarks (5\% } \\
\text { Level) }\end{array}$ \\
\hline \multirow{2}{*}{ ES } & $\begin{array}{l}\text { Between } \\
\text { Groups }\end{array}$ & 193.11 & 96.656 & 3.241 & 0.041 & S \\
\cline { 2 - 5 } & Within Groups & 8858.276 & 29.826 & & & \\
\hline
\end{tabular}




\begin{tabular}{|c|c|c|c|c|c|c|}
\hline \multirow[t]{2}{*}{ EP } & $\begin{array}{l}\text { Between } \\
\text { Groups }\end{array}$ & 144.175 & 72.826 & \multirow[t]{2}{*}{2.035} & \multirow[t]{2}{*}{0.133} & \multirow[t]{2}{*}{ NS } \\
\hline & Within Groups & 10522.742 & 35.43 & & & \\
\hline \multirow[t]{2}{*}{$\mathrm{SA}$} & $\begin{array}{l}\text { Between } \\
\text { Groups }\end{array}$ & 167.541 & 83.771 & \multirow[t]{2}{*}{2.545} & \multirow[t]{2}{*}{0.080} & \multirow[t]{2}{*}{ NS } \\
\hline & Within Groups & 9775.375 & 32.914 & & & \\
\hline \multirow[t]{2}{*}{ PI } & $\begin{array}{l}\text { Between } \\
\text { Groups }\end{array}$ & 152.822 & 76.411 & \multirow[t]{2}{*}{2.088} & \multirow[t]{2}{*}{0.126} & \multirow[t]{2}{*}{ NS } \\
\hline & Within Groups & 10870.575 & 36.601 & & & \\
\hline \multirow[t]{2}{*}{ I } & $\begin{array}{l}\text { Between } \\
\text { Groups }\end{array}$ & 62.806 & 31.403 & \multirow[t]{2}{*}{1.046} & \multirow[t]{2}{*}{0.353} & \multirow[t]{2}{*}{ NS } \\
\hline & Within Groups & 8919.861 & 30.003 & & & \\
\hline \multirow[t]{2}{*}{ Total } & $\begin{array}{l}\text { Between } \\
\text { Groups }\end{array}$ & 3250.594 & 1625.297 & \multirow[t]{2}{*}{3.096} & \multirow[t]{2}{*}{0.047} & \multirow[t]{2}{*}{$\mathrm{S}$} \\
\hline & Within Groups & 155917.042 & 524.973 & & & \\
\hline
\end{tabular}

From the table 6 it is clear that the $\mathrm{P}$ - value is greater than 0.05 for the dimensions emotional progression, Social adjustment, personality integration and independence at 5\% level of significance. Hence the null hypothesis is accepted. It shows that there is no significant difference among early adolescents in their emotional maturity with regard to age.

From the table 6 it is clear that the P - value is less than 0.05 for the dimension emotional stability and in total at $5 \%$ level of significance. Hence the null hypothesis is not accepted. It shows that there is significant difference among early adolescents in their emotional maturity with regard to age.

Table 6(a): Scheffe test results of significance of difference among early adolescents in their emotional maturity with regard to age

\begin{tabular}{|l|l|l|l|l|}
\hline \multirow{2}{*}{ Dimension } & \multicolumn{3}{|c|}{ Age } & \multirow{2}{*}{ Remarks } \\
\cline { 2 - 4 } & Age 13 & Age 14 & Age 15 & \\
\hline & -- & 20.5791 & 19.5833 & $*$ \\
\hline Emotional & 16.2000 & -- & 19.5833 & -- \\
\hline Stability & 16.2000 & 20.5791 & -- & $*$ \\
\hline
\end{tabular}

The scheffe test result shows that there is significant difference between age 14 and age 15, age 13 and age 14 in their emotional stability. The mean value of age 14 is greater than that of the others. It indicates that the age 14 students have better emotional stability than the others.

H05: There is no significant relation between aggressive behaviour and emotional maturity of early adolescents.

Table 7: Significance of relation between aggressive behaviour and emotional maturity of early adolescents

\begin{tabular}{|c|c|c|c|}
\hline Variables & $\mathbf{N}$ & $\mathbf{r}$ & Remarks (5\% level) \\
\hline Aggressive Behaviour \&Emotional Maturity & 300 & 0.562 & NS \\
\hline
\end{tabular}


From the table 4.23 it is clear that the $r$ - value is greater than 0.05 for all the dimensions at $5 \%$ lend of significance. Hence the null hypothesis is accepted. It shows that there is no significant relation between aggressive behaviour and emotional maturity of early adolescents.

\section{Findings}

- There is significant difference between male and female early adolescents in their aggressive behaviour.

- There is significant difference in aggressive behaviour of early adolescents with regard to age.

- There is no significant difference between male and female early adolescents in their emotional maturity.

- There is no significant difference among early adolescents of age 13,14 and age 15 in their emotional progression, social adjustment, personality integration, and independence. But there is significant difference among age 13, age 14 and age 15 early adolescents in the emotional stability.

- There is no significant relation between aggressive behavior and emotional maturity of early adolescents.

\section{Recommendations}

Aggressive behaviour is the reactionary and impulsive behaviour. The role of education is the modification of behaviour of the individual. So school has a great role in mending the behaviour of the students. Moral education and meditation can be given to students. This may help them to get rid of the aggressive behaviour.

The teachers are more responsible in reducing the aggressive behaviour of students. The teacher should act as a friend and guide. There should be a good rapport between the teacher and students. So that students may approach the teacher in discussing their personal problem and behaviours. So that proper counseling can be given to students. Teacher can instruct and suggest the students to watch useful programmes on television and play computer and video games which do not kindle the aggressive behaviour of the students.

Parents should keep an eye on their children not to watch violent programmes on television, internet and not to play violent computer and video games. Schools can organize community service programmes which may help the students to know the weaker section of the society and it helps them to modify them. Parents can also teach good values to help others and they should exhibit good behaviour before their children.

Teacher must play an important role in developing emotional maturity of the students. They should make the children gradually learn how to cope with real life. The students should be trained to realize and respect the emotions of others. Classes on value education and personality development can be conducted in schools to inculcate new values and create leadership qualities. Teachers can create a positive classroom environment, so that it helps the children to express their emotions freely in the Classrooms. This may create self-confidence among the children. 


\section{References}

[1] Aggarval, J.C. (2005). Essential's of educational psychology. UBS, New Delhi Kothari. C.R. (2011). Research methodology and techniques, VinajRakheja Meerut. Aggressive behaviour Retrieved from http://www.fightdementia.org.au/services/aggressive $\neg$ behaviour.aspx.

[2] Aggressive behaviour Retrieved from lutp://www.alzheimers.org.tik/site/scripts/ documents info.php? documents $1 \mathrm{D}=96$.

[3] Balakrishnan, V. \&Visvanathan, G. (2012). Value pattern of teachers in relation to social and emotional maturity, 'Meston journal of research in education, 12(2).

[4] Bhardwaj, J.S. (2012). Perceived parental behaviour in relation to emotional maturity among adolescents, Journal of Community Guidance \& Research. 29(1) 187-158.

[5] Brsibiltari \& Surwade, (2006). The effect on emotional maturity on teacher effectiveness, Edutrack, 6(1).

[6] Chakraborty, N. (2007). Principle and practice of education, Vinajrakhejameerut.

[7] Chaubc \& Akhilesh, (2007). Social Psychology, Neelkamal New Delhi.

[8] Crow \& crow, (2008). Child development and adjustment.Jurjeet publication Delhi.

[9] Dandapani.S, (2010). Advanced education psychology, Anmol New Delhi.

[10] David, D.R. (2009). Aggression and spirituality among veterans with chronic combat-related posttraumatic stress disorder. Dissertation abstracts international, P:74.

[11] Golden, S. A. R. (2011). An Analysis of Mental Stress In Heavy Alloy Penetrator Project, Tiruchirappalli. SELP Journal of Social Science, 13. 